\title{
VENOUS THROMBOSIS IN ACUTE INFANTILE HEMIPLEGIA
}

\author{
BY \\ R. G. MITCHELL \\ From the Department of Child Life and Health, University of Edinburgh, and the Royal Hospital for Sick \\ Children, Edinburgh
}

(RECEIVED FOR PUBLICATION APRIL 3, 1951)

Hemiplegia of sudden onset in children is not uncommon, and may occur in association with one of the acute infectious fevers, with a local infection such as mastoiditis or sinusitis, or in an apparently healthy child without obvious cause. Numerous series of cases have been published, one of the most important being that of Ford and Schaffer (1927) who collected 43 cases of acute hemiplegia, of which 16 followed acute infectious diseases, seven followed local infection, one was due to syphilis and 19 occurred in children considered to be healthy at the time of onset. The condition has aroused curiosity and much speculation during the past 70 years, and has been reviewed recently by Stewart (1948) and by Wyllie (1948).

Acute hemiplegia following local infection is due to cerebral venous thrombosis (Symonds, 1937 and 1940), and it is the purpose of this paper to show that many cases of acute hemiplegia in apparently healthy children are also due to this cause. Recent advances in the anticoagulant treatment of thrombosis appear to render such a review particularly apposite at the present time.

\section{Clinical Picture}

In a typical case a child under 6 years of age, who is well nourished and apparently in good health, suddenly develops a series of convulsions, and becomes unconscious for a period varying from a few hours to several days. As consciousness returns, it is found that the child has a hemiplegia, which is usually permanent to a greater or lesser degree. Sometimes there is a history of a slight upper respiratory infection, or of irritability for a day or two before the onset, but often the first convulsion occurs without warning. The convulsive movements vary from localized twitching of one arm to a generalized fit involving the whole body, and in a few cases in which the convulsions are more localized consciousness may not be lost. Occasionally there is a story of slight trauma before the onset. but such a history can be elicited about most children at any time, and its significance is difficult to assess. The hemiplegia usually improves in the weeks following the episode, especially in the lower limb, but only rarely clears up completely, and the child is often left mentally retarded, while epilepsy or involuntary movements are common at a later stage.

\section{Present Series}

Ten cases of acute hemiplegia have occurred in the medical wards of the Royal Hospital for Sick Children, Edinburgh, during the past 15 years and all survived the incident. None were associated with acute infectious fevers, as such cases are not normally admitted to this hospital. Eight of these 10 children had normal ear drums on inspection while two showed evidence of infection of the middle ear. These groups are not separated for reasons to be stated later.

Of these 10 cases, six were girls and four were boys, their ages ranging from 8 months to 5 years. All the children were well nourished, and four had a history of upper respiratory infection before the onset. Three cases had a history of trauma, one a slight blow on the head four months previously, the second a minor fall from a low chair a day before the first convulsion, and the third a slight blow on the head three days before the hemiplegia. No case had a history suggesting injury or anoxia at birth, and none was in any way retarded in early development.

The convulsions were confined to one side in three cases, involved both sides, but were most marked in the arms in three cases, and spread to involve the face, arm and leg in that order in two 
Clinical Summary

\begin{tabular}{|c|c|c|c|c|}
\hline Case & Age at Onset & Sex & Previous Health & Features of Onset \\
\hline 1 & 8 months & F. & $\begin{array}{l}\text { Normal birth } \\
\text { B.W. } 7 \frac{1}{2} \text { lb. } \\
\text { No past illnesses }\end{array}$ & $\begin{array}{l}\text { Slight cough and vomited three times; } \\
36 \text { hours later, right-sided convulsion } \frac{\bar{\sigma}}{\frac{\bar{\sigma}}{\bar{\sigma}}}\end{array}$ \\
\hline 2 & $\begin{array}{l}2 \text { years, } \\
4 \text { months }\end{array}$ & M. & $\begin{array}{l}\text { Normal birth } \\
\text { B.W. } 9 \mathrm{lb} \text {. } \\
\text { Measles at } 1 \text { year }\end{array}$ & $\begin{array}{l}\text { Anorexia, and vomited twice; } \\
\text { sudden onset of twitching of right sidecon } \\
\text { same day }\end{array}$ \\
\hline 3 & 1 year & F. & $\begin{array}{l}\text { Normal birth } \\
\text { B.W. } 5 \frac{3}{4} \text { lb. } \\
\text { No illnesses except chronic nasal dis- } \\
\text { charge }\end{array}$ & $\begin{array}{l}\text { Sudden paralysis of left arm, followed } \\
\text { next day by paralysis of left leg; 他o } \\
\text { days later, general convulsions }\end{array}$ \\
\hline 4 & $\begin{array}{l}5 \text { years, } \\
3 \text { months }\end{array}$ & M. & $\begin{array}{l}\text { Normal birth } \\
\text { Pertussis and chickenpox } \\
\text { Minor head injury four months before }\end{array}$ & $\begin{array}{l}\text { Sudden complete left hemiplegia } \\
\text { No convulsive movements }\end{array}$ \\
\hline 5 & 1 year & $\mathrm{F}$. & $\begin{array}{l}\text { Normal birth } \\
\text { B.W. } 7 \text { lb. } \\
\text { Rubella at four months }\end{array}$ & $\begin{array}{l}\text { Two days irritability, then twitching of } \\
\text { left side of face, spreading to left arm } \\
\text { and leg }\end{array}$ \\
\hline 6 & $\begin{array}{l}1 \text { year, } \\
4 \text { months }\end{array}$ & F. & $\begin{array}{l}\text { Normal birth } \\
\text { B.W. } 7 \text { lb. } \\
\text { No illnesses }\end{array}$ & $\begin{array}{l}\text { Two weeks irritability and coryza, sudfigen } \\
\text { right-sided twitching. Recovered. } \\
24 \text { hours later, left-sided twitching }\end{array}$ \\
\hline 7 & 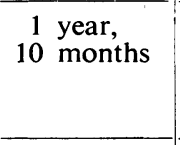 & M. & $\begin{array}{l}\text { Normal birth } \\
\text { B.W. } 7 \text { lb. } \\
\text { No illnesses }\end{array}$ & $\begin{array}{l}\text { Head cold. Six days later, vomited } \\
\text { and had generalized convulsions, maxîng } \\
\text { in arms }\end{array}$ \\
\hline 8 & 10 months & $\mathrm{F}$. & $\begin{array}{l}\text { Normal birth } \\
\text { B.W. } 7 \frac{1}{2} \text { lb. } \\
\text { Bronchitis at } 6 \text { months }\end{array}$ & $\begin{array}{l}\text { Sudden twitching of arms and mol्gh. } \\
\text { Recovered but still drowsy. Two dक्षys } \\
\text { later, generalized convulsion }\end{array}$ \\
\hline 9 & $\begin{array}{l}1 \text { year, } \\
6 \text { months }\end{array}$ & F. & $\begin{array}{l}\text { Normal birth } \\
\text { B.W. } 7 \mathrm{lb} \text {. } \\
\text { Bronchitis at } 6 \text { months }\end{array}$ & $\begin{array}{l}\text { Fretful for two days, sudden twitching } \\
\text { right arm and leg, followed by lossof } \\
\text { consciousness }\end{array}$ \\
\hline 10 & $\begin{array}{l}2 \text { years, } \\
4 \text { months }\end{array}$ & M. & $\begin{array}{l}\text { Normal birth } \\
\text { Twin } \\
\text { Chickenpox, measles and pertussis }\end{array}$ & $\begin{array}{l}\text { Respiratory infection three weeks prifi- } \\
\text { ously. Four days irritability; minor } \\
\text { blow on head three days before onset }\end{array}$ \\
\hline
\end{tabular}

cases. Two cases had sudden paralysis without convulsive movements. The hemiplegia was on the right side in five cases, and on the left in five cases. No changes were noted in the optic fundi except in one case which will be described in detail later.

The white blood cell count ranged from 8,000 to 33,000 per c.mm. The cerebrospinal fluid was under normal pressure in all cases, and its cell content varied from no cells to 100 per c.mm. The protein in the cerebrospinal fluid was raised to $85 \mathrm{mg}$. \% in one case, was normal in eight, and was not estimated in one owing to contamination with blood. In all cases the fluid was sterile on culture.

After an average follow-up period of three years all the children had some residual signs of hemiplegia,.and three showed some degree of mental retardation. Contrary to most reports, none has so far developed epilepsy, but the onset of this may be delayed for some years.

The main features of these 10 cases are summarized in Table 1. 
1 OF TEN Cases

\begin{tabular}{|c|c|c|c|}
\hline Findings on Admission & C.S.F. & Temperature & End-Results \\
\hline $\begin{array}{l}\text { Conscious; right hemiplegia; well } \\
\text { nourished }\end{array}$ & $\begin{array}{l}\text { No cells } \\
\text { P. } 85 \mathrm{mg} . \% \\
\text { S. } 41 \mathrm{mg} . \% \\
\text { Ch. } 648 \mathrm{mg} \%\end{array}$ & $102 \cdot 8^{\circ} \mathrm{F}$ & $\begin{array}{l}\text { One month later, still paralysed. } \\
\text { Did not attend follow-up clinic. }\end{array}$ \\
\hline $\begin{array}{l}\text { Unconscious; twitching of right side, } \\
\text { later right hemiplegia; well nourished }\end{array}$ & $\begin{array}{l}\text { No cells } \\
\text { P. } 20 \mathrm{mg} . \% \\
\text { S. } 94 \mathrm{mg} . \% \\
\text { Ch. } 696 \mathrm{mg} . \%\end{array}$ & $105 \mathrm{~F}$. & $\begin{array}{l}\text { Ten years later, right hand still clumsy, } \\
\text { leg almost normal. Average intelligence. } \\
\text { No fits. }\end{array}$ \\
\hline $\begin{array}{l}\text { Conscious; left hemiplegia ; well } \\
\text { nourished }\end{array}$ & $\begin{array}{l}\text { No cells } \\
\text { P. } 25 \mathrm{mg} . \% \\
\text { S. } 35 \mathrm{mg} . \% \\
\text { Ch. } 736 \mathrm{mg} .\end{array}$ & $98 \cdot 4^{\circ} \mathrm{F}$ & $\begin{array}{l}\text { Eight years later, using left hand very } \\
\text { little. Slight limp. Normal intelligence. } \\
\text { No fits. }\end{array}$ \\
\hline $\begin{array}{l}\text { Conscious; left hemiplegia ; well } \\
\text { nourished }\end{array}$ & $\begin{array}{l}\text { No cells } \\
\text { P. } 20 \mathrm{mg} . \% \\
\text { S. } 68 \mathrm{mg} . \% \\
\text { Ch. } 702 \mathrm{mg} \%\end{array}$ & $98 \cdot 8 \mathrm{~F}$ & $\begin{array}{l}\text { Six years later, still weakness of left } \\
\text { arm and leg. Backward at school. } \\
\text { No fits. }\end{array}$ \\
\hline $\begin{array}{l}\text { Unconscious ; general convulsions, } \\
\text { later left hemiplegia; well nourished }\end{array}$ & $\begin{array}{l}\text { Blood-stained } \\
\text { S. } 71 \mathrm{mg} . \% \\
\text { Ch. } 720 \mathrm{mg} . \%\end{array}$ & $106 \cdot 4 \mathrm{~F}$ & $\begin{array}{l}\text { Three years later, left hand clumsy, } \\
\text { occasional athetoid movements. } \\
\text { Mentally normal. No fits. }\end{array}$ \\
\hline $\begin{array}{l}\text { Semi-conscious; left hemiplegia; well } \\
\text { nourished }\end{array}$ & $\begin{array}{l}50 \text { lymphocytes } \\
\text { P. } 28 \mathrm{mg} . \% \\
\text { S. } 54 \mathrm{mg} . \% \\
\text { Ch. } 770 \mathrm{mg} . \%\end{array}$ & $101 \mathrm{~F}$. & $\begin{array}{l}\text { Two years later, left hemiplegia only } \\
\text { slightly improved. Mentally backward. } \\
\text { No fits. }\end{array}$ \\
\hline $\begin{array}{l}\text { Unconscious; general spasticity, later } \\
\text { left hemiplegia; well nourished }\end{array}$ & $\begin{array}{l}2 \text { cells } \\
\text { P. } 28 \mathrm{mg} . \% \\
\text { S. } 95 \mathrm{mg} . \% \\
\text { Ch. } 720 \mathrm{mg} . \%\end{array}$ & $102 \cdot 6 \mathrm{~F}$ & $\begin{array}{l}\text { Five months later, left arm can be } \\
\text { moved, fingers clumsy. Mentally re- } \\
\text { tarded. No fits. }\end{array}$ \\
\hline $\begin{array}{l}\text { Semi-conscious ; right hemiplegia ; } \\
\text { well nourished }\end{array}$ & $\begin{array}{l}100 \text { lymphocytes } \\
\text { P. } 25 \mathrm{mg} . \% \\
\text { S. } 75 \mathrm{mg} . \% \\
\text { Ch. } 730 \mathrm{mg} . \%\end{array}$ & $105 \cdot 8^{\circ} \mathrm{F}$ & $\begin{array}{l}\text { Three months later, slight residual } \\
\text { hemiplegia. Probably normal intelli- } \\
\text { gence. No fits. }\end{array}$ \\
\hline $\begin{array}{l}\text { Unconscious ; continuous right-sided } \\
\text { convulsions; well nourished }\end{array}$ & $\begin{array}{l}4 \text { lymphocytes } \\
\text { P. } 35 \mathrm{mg} . \% \\
\text { S. } 150 \mathrm{mg} . \% \\
\text { Ch. } 765 \mathrm{mg} . \%\end{array}$ & $105 \cdot 6 \mathrm{~F}$ & $\begin{array}{l}\text { Eight months after onset, still marked } \\
\text { weakness on right side. Normal men- } \\
\text { tally. No fits. }\end{array}$ \\
\hline $\begin{array}{l}\text { Semi-conscious; right hemiplegia } \\
\text { and right homonymous hemianopia ; } \\
\text { well nourished }\end{array}$ & $\begin{array}{l}10 \text { lymphocytes } \\
\text { P. } 21 \mathrm{mg} . \% \\
\text { S. } 60 \mathrm{mg} . \% \\
\text { Ch. } 715 \mathrm{mg} . \%\end{array}$ & $99 \cdot 8^{\circ} \mathrm{F}$. & $\begin{array}{l}\text { Two months later, using left hand more } \\
\text { than right. Hemianopia still present. } \\
\text { Probably normal mentally. No fits. }\end{array}$ \\
\hline
\end{tabular}

Aetiology of the Condition

Various authors have speculated on the possible causes of acute infantile hemiplegia, but all have been handicapped by the fact that most patients survive, while those who die may do so in the acute stage when it cannot be certain that hemiplegia exists. Most of the necropsies reported have been carried out long after the onset of paralysis, and as Ford and Schaffer (1927) point out, little or nothing can be inferred from the end-results in such cases.

The theory that the condition is due to polio- encephalitis (Strümpell, 1884) held sway for many years, but this hypothesis was based on clinical impressions and not on pathological evidence, and the virus of poliomyelitis has never been demonstrated.

Goodhart, quoted by Abercrombie (1887), suggested that the convulsions themselves might cause cerebral congestion and haemorrhage, but this has not been substantiated by necropsy evidence from other cases. Abercrombie himself suggested embolism, and though this may cause hemiplegia 
in cases with heart disease, it seems an unlikely explanation in the majority of cases. Norman (1947) believes that birth injury plays some part in the pathogenesis, and that sufficient cortical tissue is spared to mask the original lesion for a time. This is not borne out by the cases presented in the present series, all of which had a normal birth history, the usual finding in these cases.

It is now widely held that many cases are due to vascular lesions, probably thrombotic in nature, and arterial rather than venous. Some authors have described changes in the arteries themselves, but although a few of these cases must be accepted, many are not convincing. For example, the often quoted case in which Ghetti (1909) described endarteritis, was a boy of 10 years, who already had a facial paralysis before his sudden hemiplegia and therefore hardly fits the conception of acute infantile hemiplegia. Ghetti himself thought that the condition was syphilitic, although he could not demonstrate the spirochaete. Most cases of cerebral endarteritis in infancy without hemiplegia have a previous history suggesting syphilis or meningitis, as in the case described by Altschul (1949).

\section{Venous Thrombosis}

Gowers (1888) suggested that the lesion might be thrombosis in a vein, and although this idea has not met with any general favour, more recent work lends support to his view. It was formerly held that extensive intracranial venous thrombosis would usually cause death, but it is now well known that patients with lateral sinus thrombosis frequently recover, and even extensive thrombosis of the superior longitudinal sinus may not be fatal (Ellis, 1937; Bailey and Hass, 1937a). Focal cerebral signs are known to occur dramatically without other indications of venous thrombosis, and such cases in the past have often been erroneously attributed to arterial thrombosis or to encephalitis (Symonds, 1940). In the few recorded cases of acute infantile hemiplegia where death has occurred in the acute stage most of the brains have shown gross vascular lesions, sometimes haemorrhage and sometimes softening, and no cause has been found for these appearances in the majority of instances (Stewart, 1948). The occurrence of softening secondary to venous thrombosis often results in haemorrhage, and Courville and Nielsen (1935) state that cortical venous thrombi may disappear after giving rise to gross changes in the brain.

In some cases a non-specific encephalopathy, such as occurs in infectious fevers, has been noted (Wyllie, 1948), and Putnam (1937) found that the acute lesion of venous thrombosis corresponds in all its details with that which is considered character- istic of encephalomyelitis following infectious diseases. Signs of obstruction of the lateral sinus need not be present, as it is not necessary for the thrombus to occlude the sinus to produce its effect (Symonds, 1937).

Any explanation of the cause of the hemiplegia must account for the observed maximum involvement of the upper limb, with convulsive movements frequently starting in the face, spreading to the hand and arm, and after an interval to the leg. Only a slowly extending lesion of the cerebral cortex could produce this ordered progression of localized convulsions, and followed as it usually is by a paralysis which only partly recovers, such a lesion is more likely to be venous thrombosis than anything else. The finding in other cases of convulsive movements on one side followed after an interval by movements on the other side, or of a gradual onset of convulsions spread over several days, makes it difficult to conceive of any process but venous thrombosis as a cause.

Merwarth (1942) and others consider that spread of thrombosis from the superior longitudinal sinus into the superficial middle cerebral vein (Rolandic vein) usually produces a characteristic initial involvement of the leg, with subsequent spread to the arm and finally to the hand which is least affected. However, Symonds (1940) pointed out that the pattern, while to be expected, is not constant, and Dowman (1926) described a case in which the reverse sequence of events took place. The following case would seem to bear out Merwarth's observations on the so-called Rolandic syndrome.

Case Demonstrating the "Rolandic Syndrome"

Case 11. A girl, aged 15 months, was admitted on January 7, 1951. Delivery had been spontaneous. Birth weight was $5 \frac{1}{2} \mathrm{lb}$. The infant thrived well, passing the milestones normally, and had no illnesses.

The infant was healthy until three days before admission, when the left foot suddenly began to twitch. Two hours later, the left arm began to twitch, and then the left side of the face. Seven hours after onset the child lost consciousness, and after a further six hours the right foot began to twitch, and the movements spread gradually up to involve the right arm and the right side of the face. Occasional twitches continued on both sides, but gradually diminished in frequency. She vomited just after the onset, but not again. Her temperature rose to $106=\mathrm{F}$.

On admission, she was seen to be a well nourished child, deeply unconscious. There was no increased tension of the anterior fontanelle, and the optic fundi were normal. The knee and ankle jerks were present and equal, the right plantar response was flexor and the left extensor. The abdominal reflexes were absent. Apart from occasional twitching of the right hand, no other abnormality was found in the nervous system. 
The cerebrospinal fluid was not under pressure, and contained five lymphocytes and a few red cells per c.mm. The protein was $24 \mathrm{mg} .{ }^{\circ}$, the sugar $128 \mathrm{mg} . \%$ and the chlorides $890 \mathrm{mg} .{ }^{\circ}{ }^{\circ}$. Culture was sterile. The white blood cell count was 31,000 per c.mm., and blood culture from the internal jugular vein was also sterile.

Death occurred a few hours after admission, and necropsy showed firm ante-mortem thrombosis of the superior longitudinal sinus and adjacent cortical veins, with more recent ante-mortem thrombus in both lateral sinuses, and some overlying subarachnoid haemorrhage. Both ears were healthy, and post-mortem cultures from ears and meninges were sterile. Microscopically, the walls of the veins were infiltrated by polymorphonuclear leucocytes, which were also numerous in the surrounding meninges and cortex (Fig. 1). Small collections of these cells were found

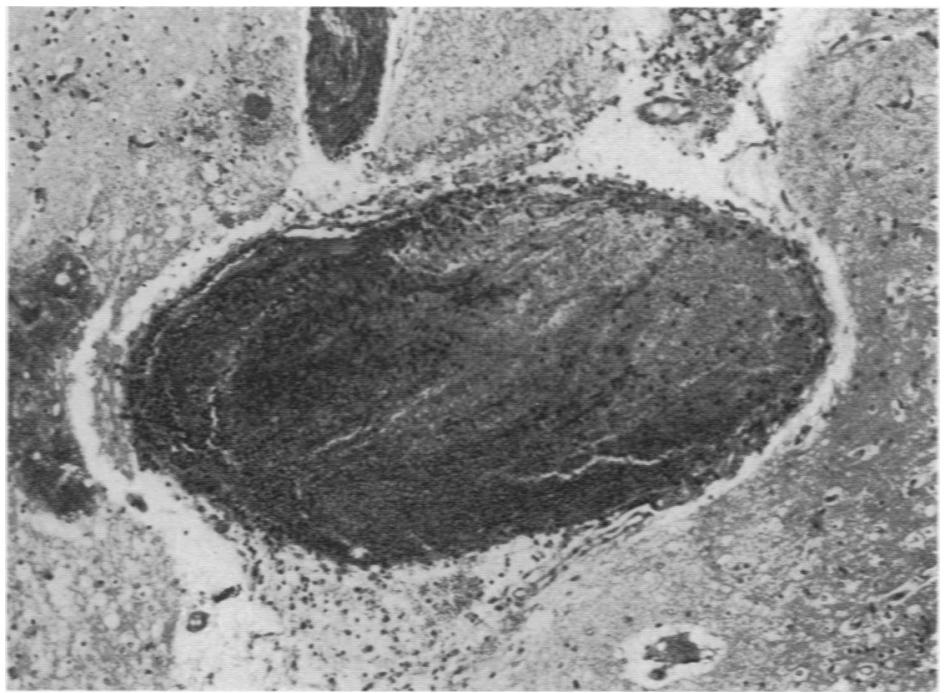

FIG. 1.-Photomicrograph of thrombosed cerebral vein (Case 11) showing polymorph infiltration of thrombus and surrounding tissues. $\mathrm{H}$. and $\mathrm{E}$. $\times 60$. was present, but no primary focus could be demonstrated.

It seems probable, therefore, that the reverse sequence of events observed in some cases of acute infantile hemiplegia could be explained by thrombosis spreading in the opposite direction. This might arise spontaneously in a cortical vein, as suggested by Gowers (1888), but there seems no valid reason why such a process should so consistently start in the cortical veins in the upper limb area of the motor cortex. A much more reasonable explanation is that in these cases the thrombosis spreads via the lateral sinus to the inferior anastomotic vein (vein of Labbé), which is frequently a wide channel. Courville and Nielsen (1935) described this mode of spread in discussing 23 cases of cerebral manifestations of otitis media, 17 of which showed paralysis affecting the arms before the legs and to a greater degree. They suggest that this mode of spread may occur only when the inferior anastomotic vein opens near the junction of the superior petrosal sinus with the lateral sinus, and not when it opens more caudally. These authors also point out that the chain of thrombosis need not be continuous, and that the process may spread through the lateral sinus to the cortical veins without extensive involvement of the sinus itself.

It has been thought that the onset of coma is caused by widespread circulatory disturbance of the cortex, due to extension of the thrombus to the torcular herophili (Salinger, 1923) or into the superior longitudinal sinus (Byers and Hass,
1933). Recent views on consciousness, however, suggest that global affections of consciousness are due to interference with the basal nuclear system, probably the anterior part of the corpus striatum in particular (Dandy, 1946). This could be produced by extension of the thrombosis into the internal cerebral veins, either by way of the straight sinus and the great vein of Galen, or by the cavernous sinus, but it could also be due to the effects of venous stasis, causing impairment of the circulation to the basal nuclei or their connexions. Campbell (1938) emphasized how little we know of the effects of venous stasis in the central nervous system, and that we should keep in mind the possibility of the occurrence of stasis of a reversible kind as a cause of parenchymal damage. Cortical venous thrombosis is usually accompanied by oedema which causes shift of the intracranial contents, and such anatomical derangements will $\cdot$ also interfere with the basal nuclei, partly by affecting the circulation and partly by direct pressure.

Why a sudden paralysis should occur in some cases without convulsions is difficult to explain. Paralysis instead of convulsive movements has been noted in local epilepsy due to trauma, and Holmes (1927) considered that it was caused by primary inhibition instead of excitation of the cortical motor elements. It must also be remembered that, just as there is an inborn susceptibility to convulsions in epilepsy, so there may be individuals who are constitutionally resistant to convulsive agents. When the paralysis is permanent, as in acute 
infantile hemiplegia, it may be due to a more rapid initial destruction of nervous elements than occurs in those cases which start with convulsions (Purdon Martin, 1944).

Two of the present series of cases presented unusual features which support the conception of venous thrombosis as a cause of acute infantile hemiplegia. They are therefore described in greater detail.

\section{Cases Supporting Aetiology of Venous Thrombosis}

Case 7. A boy, aged 1 year and 10 months, was admitted on October 31, 1950. Birth had been normal. Birth weight was $7 \mathrm{lb}$. The milestones had been passed normally, and the child had had no previous illnesses.

For one week before admission he had a slight coryza. Forty-eight hours before admission he lost his appetite, and on the same day he had a fall from a low chair with no obvious ill effects. He vomited twice next day, and had one loose stool. That night he had a series of convulsions, affecting principally the arms, and he was admitted to hospital unconscious, with a temperature of $102 \cdot 6$ F.

He was a well nourished child, with slight generalized spasticity of the limbs. The knee and ankle jerks were less brisk on the left side, and the plantar responses were equivocal. The optic fundi were normal. The ear drums were obscured by wax, but when this was removed they appeared normal.

The skull was normal radiologically, and the white blood cell count was 12,000 per c.mm. The cerebrospinal fluid was not under pressure, contained two cells per c.mm., with protein $28 \mathrm{mg}$. ${ }_{0}^{\circ}$, sugar $95 \mathrm{mg} .{ }_{0}^{\circ}$, and chlorides $720 \mathrm{mg} .{ }_{0}^{\circ}$.

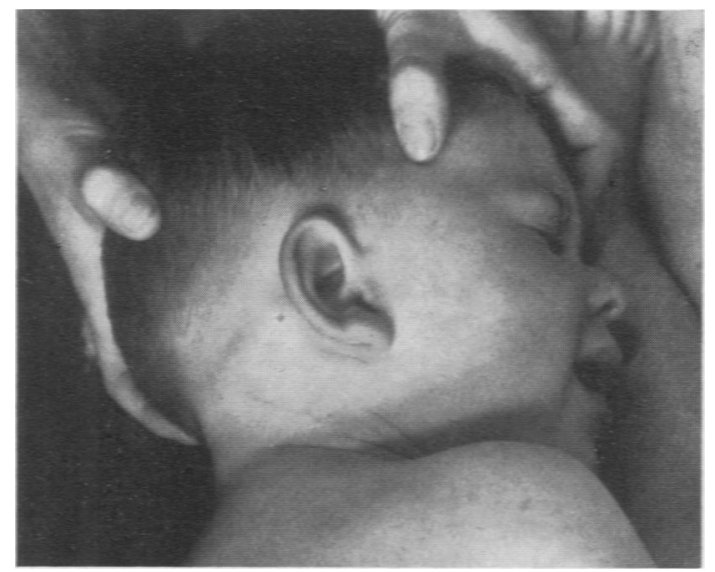

FIG. 2a.-Thrombosed mastoid emissary vein in Case 7.

He had no further convulsions. but remained in a semi-conscious state. Next day his left arm was found to be weak, and on the following morning it was obvious that he had a left hemiplegia, with extensor plantar response on that side. He was treated with penicillin and streptomycin, and three days later it was noticed that the right mastoid emissary vein was firmly thrombosed (Fig. 2a). Treatment with heparin was started. He remained completely uninterested in his surroundings, but his general condition improved, and the paralysis gradually became less marked. By five weeks after the onset he could sit up but still seemed lacking in perception, not even recognizing his parents. During the next two weeks he made further progress, and was finally discharged seven weeks after onset. Three months later the left arm was still very weak and clumsy, and the leg was slightly weak, while he was still obviously mentally retarded. The thrombosed mastoid vein was still easily palpable. Fig. $2 b$ shows the child five months after the onset of hemiplegia.

Case 8. A girl, aged 10 months, was admitted on November 22, 1950 . Birth had been normal. Birth weight was $7 \frac{1}{2} \mathrm{lb}$. She thrived well until 60 hours before admission, when her arms and mouth suddenly began to twitch, and she became very limp. After a while the twitching stopped and the baby recovered a little, but during the next 24 hours she was drowsy and vomited several times. On the day before admission generalized convulsions started and continued until admission, when she was found to be semi-conscious, with a right hemiplegia.

The child's nutrition was good, and there was no

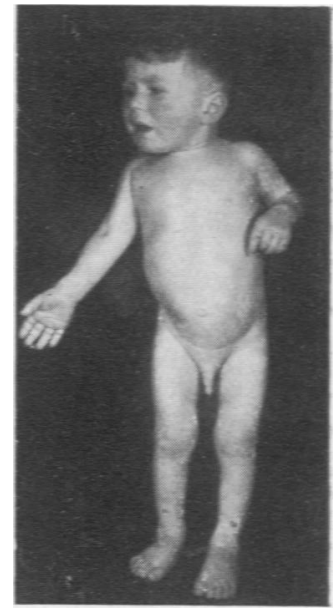

FIG. 2b.- The child five months after the onset of hemiplegia. increase of tension in the anterior fontanelle. The ear drums were normal. All limb reflexes were present, and no marked difference could be demonstrated between the two sides. The abdominal reflexes were absent.

The white blood cell count was 10,000 per c.mm. The cerebrospinal fluid was under normal pressure. and contained 100 lymphocytes per c.mm., with protein $25 \mathrm{mg} .{ }^{\circ}$, sugar $75 \mathrm{mg} .{ }^{\circ}$ o and chlorides $730 \mathrm{mg}$. ${ }^{\circ}{ }_{0}$.

The left optic fundus (Fig. 3) showed a large haemorrhage almost obscuring the disc and extending temporally to the macula. The outline of the haemorrhage was irregular in shape, but the lower border was well defined and convex downwards, the appearance being fairly typical of pre-retinal bleeding. The arteries appeared normal, but the veins showed some congestion. There were also two or three small haemorrhages in relation to the veins above and nasal to the disc. The appearances were similar in the right fundus.

The child had several right-sided convulsions after admission, and then gradually recovered. Three months later she was still not using the right hand as much as the left, and tended to drag the right foot a little. She had no further fits, and appeared normal mentally. 


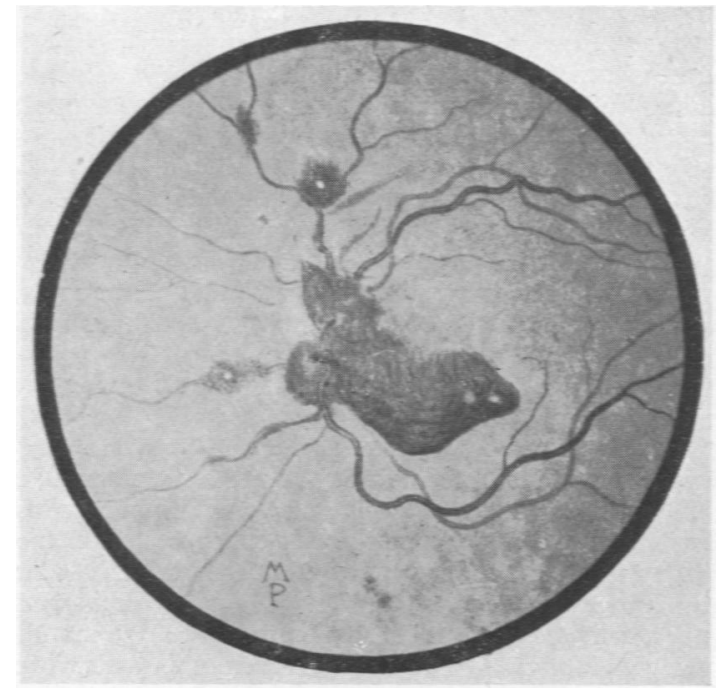

FIG. 3.-Fundus of left eve in Case 8 (drawn by Dr. Maurice Paterson).

Case 7 showed many of the typical features of acute infantile hemiplegia. The history of a slight fall was only elicited by direct questioning, and was so slight that its significance in the aetiology is doubtful. The thrombosis in the mastoid emissary vein must almost certainly have spread from the lateral sinus. There was no sign of local sepsis.

In Case 8 the onset was rather prolonged, but otherwise typical. Dr. G. I. Scott, of the Eye Department, Royal Infirmary of Edinburgh, considered that the bleeding was certainly not due to local arterial or venous obstruction, and that the changes could only be explained by a sudden rise in venous pressure, as extensive subarachnoid haemorrhage was excluded by the results of lumbar puncture.

The mastoid emissary vein and the central vein of the retina form the two visible ends of an intracranial venous chain extending from the lateral sinus by the superior petrosal sinus to the cavernous sinus, and it is into this chain that the inferior anastomotic vein opens. In these two cases the thrombosis has presumably spread towards the ends of the chain, the mastoid and the retinal ends respectively. It is to be noted that neither of these cases showed the raised chlorides in the cerebrospinal fluid considered by Ebbs (1937) to be characteristic of thrombosis, but this is probably due to the greater severity of the process in his cases, for as Symonds (1937) has pointed out, in fatal cases there is usually very extensive occlusion of cerebral veins. The increased cell count in Case $\mathbf{8}$ is not unusual, as Symonds found that about half of the cases of hemiplegia following thrombophlebitis had a pleiocytosis in the cerebrospinal fluid.

Why should such a thrombosis occur in an apparently healthy child ? Thrombosis of the dural sinuses is usually described as being of two types, marantic and septic, the former occurring in ill, dehydrated children, and the latter showing all the signs of fulminating sepsis (Toomey and Hutt, 1949). In such circumstances, stasis and altered coagulability of the blood are likely to be of importance, but these factors must play a small part when, as in Case 11, focal cerebral signs are the first indication of disease. Infection may cause injury to vessel walls, possibly by the effects of bacterial products in the blood stream, and Case 11 shows that there may be no indication of the site of the original infection, even though there is post-mortem evidence that infection was present.

In Ebbs' series of 32 cases of cerebral sinus thrombosis in children every patient showed evidence of infection at necropsy, even when it was not demonstrable during life, and this was the only common factor (Ebbs, 1937). Beck and Russell (1946), in reviewing cases of aseptic thrombosis, were struck by the frequency of infective processes in some part of the body, and suggested that a possible mechanism was a localization of infection from a distant source by a process analogous with the Schwartzmann phenomenon. They were unable to reproduce this experimentally, however.

Thrombosis may occur in the veins in the course of infections of various sorts, but is not necessarily itself infected (Putnam and Alexander, 1938). The finding of inflammatory cells in the walls and perivascular tissues of thrombosed veins is not necessarily evidence of infection, and may occur in the absence of bacteria (Byers and Hass, 1933).

Pyrexia at the onset of acute infantile hemiplegia has been adduced as an indication of infection (Courville and Nielsen, 1935), but Bailey and Hass (1937b) have pointed out that dural sinus thrombosis itself is a cause of fever, possibly by interference with the central control of temperature regulation.

\section{Role of Infection of the Upper Respiratory Tract}

It is well known that thrombosis in the lateral sinus may follow otitis media and mastoiditis, but it may also be caused by naso-pharyngeal infection, however insignificant, and a latent period up to as long as four weeks may follow a tonsillar infection (Goldman, 1936; Maybaum, 1936). In reviewing past cases of acute infantile hemiplegia in apparently healthy children Courville and Nielsen (1935) were of the opinion that minor changes in the membrana tympani, now recognized as responsible for serious complications, may not have been mentioned owing 
to under-estimation of their importance. Chronic inflammatory changes are not necessary in the bone and dura for invasion of the subdural spaces, and lateral sinus thrombosis can occur very early in acute otitis media, when clinical signs of the latter condition are minimal or absent. These authors emphasize that the often scarcely detectable and apparently insignificant changes in the drums must be considered as possible aetiological factors in manifest intracranial lesions, and have too often been ignored in the past. It is interesting to note that in one of their cases of hemiplegia with otitis cortical changes were found corresponding to those described by Ford and Schaffer (1927), which the latter authors ascribed to arterial thrombosis.

Cases 9 and 10 are examples of the type of case which Courville and Nielsen describe.

\section{Cases Demonstrating Inflammatory Change as an Aetiological Factor}

Case 9. A girl, aged 18 months, was admitted on March 5, 1950. Birth had been normal. Birth weight was $7 \mathrm{lb}$. The milestones were normal. She had bronchitis at 6 months; there were no other illnesses. She was healthy until two days before admission, when she became a little fretful, but otherwise seemed well. Three hours before admission the right arm and leg suddenly began to twitch, and she rapidly lost consciousness, her temperature rising to $105 \cdot 6^{\mathrm{C}} \mathrm{F}$.

On admission she was seen to be a well nourished child, with continuous convulsive movements of the whole of the right side. Slightly indistinct edges were noted in the right optic disc, but these were not noted later. The right ear drum was normal, and the left was injected with loss of the light reflex. The white blood cell count was 33,000 per c.mm., and the cerebrospinal fluid contained 4 lymphocytes per c.mm., with protein $35 \mathrm{mg}$. \%, sugar $150 \mathrm{mg} .{ }^{\circ}$ and chlorides $765 \mathrm{mg} .{ }^{\circ}$.

Treatment was started with sulphamezathine, penicillin and streptomycin, and two days later heparin was added.

On the day after admission the movement stopped. but she was left with a right hemiparesis. A myringotomy was carried out on the left ear drum, but only a little muco-pus obtained.

Her general condition improved slowly, but two weeks after onset the hemiplegia was still almost complete. Physiotherapy was then started, with some improvement in function during the ensuing month, but eight months after onset the child still had marked weakness and incoordination on the right side.

Case 10. A boy, aged 2 years and 4 months, was admitted on January 29, 1951. Birth had been normal. He was a twin. Milestones were normal. He had had chickenpox, measles and pertussis.

He was well until three weeks before admission, when he developed a respiratory infection diagnosed as influenza. He recovered in a few days, but 10 days before admission the respiratory symptoms recurred, and one week later he became rather listless and lost his appetite. Three days before admission he banged his head, and though not very upset by this, he seemed rather drowsy next day. On the morning before admission paralysis of the right side of the face and the right arm developed, and a few hours later the right arm began to twitch and he became semi-conscious.

On admission, he was seen to be a well nourished child with marked weakness of the right arm and right side of the face, and slight weakness of the right leg. Apart from slight pinkness of the left ear drum, no other abnormality was found. His temperature was $99 \cdot 8^{\circ} \mathrm{F}$, and the white blood cell count was 21,000 per c.mm. The cerebrospinal fluid was not under pressure, and contained 10 lymphocytes per c.mm., and protein $21 \mathrm{mg}$. ${ }^{\circ}$, sugar $60 \mathrm{mg}$. ${ }^{\circ}$ and chlorides $715 \mathrm{mg}$. \%.

Treatment with sulphamezathine, aureomycin and heparin was started, and next day he was more conscious, and was noted to have aphasia and a right homonymous hemianopia. Six days after treatment was started the paralysis began to improve, but the aphasia and hemianopia remained complete. He was discharged three weeks after admission, and when seen one month later he had improved a great deal mentally, was saying a few words, and was using the right hand a little. The hemianopia, however, was still present.

Both these cases showed evidence of ear infection. In Case 9 there was definite left otitis media, but of recent origin and not severe, while in Case 10 there were only slight changes in the left drum.

In Case 10 there was also a history of slight trauma, and again it is difficult to be certain of the part this played in the aetiology, but as pointed out above, such a history is almost universal in small children. It is more than likely to have been coincidental, but the possibility that trauma of this mild type precipitates the thrombosis cannot be entirely excluded, as it is well known that more severe head injuries may cause sinus thrombosis (Purdon Martin, 1944).

The hemianopia noted in Case 10 is important, because it emphasizes that venous thrombosis may affect areas other than the motor cortex, in this case probably the optic radiations. Hemianopia was not noted in the other nine cases in this series, but it may well have been missed, as it is not always obvious in a young child unless especially looked for.

\section{Treatment}

In the past the majority of these cases have received only symptomatic treatment, with perhaps sedatives to control the fits. As minor infection may play a significant part in the pathogenesis, it would seem logical to administer full doses of the appropriate antibiotic from the start.

Since thrombosis has already occurred, anticoagulants cannot be used prophylactically in these cases, but they may be of value therapeutically in preventing further spread of thrombosis and possibly in dissolving the clot, as they have been shown to do 
experimentally if given early enough (Rabinovitch and Pines, 1943). In addition reabsorption of oedema is hastened by heparin therapy (de Takats, 1950) and it is reasonable to suppose that heparin would produce the same beneficial effects in intracranial thrombosis as it does in deep venous thrombosis in the leg, where the subsidence of swelling is dramatic (Bauer, 1946).

Anticoagulants have been used in intracranial thrombosis since Goodhill (1944) first treated a case of cavernous sinus thrombosis with heparin, and where there is definite evidence of thrombosis as in Cases 7 and 8, heparin is undoubtedly indicated. The danger of anticoagulant treatment is intracranial haemorrhage, and this has been known to occur where dicoumarol has been used without proper safeguards (Shlevin and Lederer, 1944), but when carefully used the risk is not great (Hines and Barker, 1949) and is certainly justified in view of the poor prognosis as regards mental attainments and physical function. Evidence of haemorrhage accompanying thrombosis, such as xanthochromia or red cells in the cerebrospinal fluid, is not a contraindication to this treatment, but caution should be exercised in selecting patients, and where the diagnosis of thrombosis is in doubt, the exhibition of anticoagulants is unwarranted (Foley and Wright, 1950).

Heparin is preferred to dicoumarol in these cases because the effect is more easily controlled, while the difficulty of obtaining venous blood at frequent intervals from children (which is necessary since micro-analytical methods have proved unreliable) also contraindicates dicoumarol. In addition, heparin acts more rapidly and its effect ceases in a few hours, and, when properly used, the tendency to bleed seldom gives trouble (Jorpes, 1946).

Heparin was used in conjunction with antibiotics in Cases 7, 9 and 10, but it is not possible to draw any conclusions as to the efficacy of treatment from these few cases. Nevertheless, theoretical considerations would indicate that such is the treatment of choice, and a short experience of its use in the Department of Surgical Neurology in Edinburgh has provided convincing evidence of its importance and value in the management of cerebral venous thrombosis (Dott, 1951).

\section{Conclusion}

The division of cases of acute infantile hemiplegia into those who have an obvious local infection and those who are apparently healthy is artificial, as many of the latter group may have ah aural or other upper respiratory infection with minimal or absent clinical signs. Venous thrombosis is the probable cause of the paralysis in many of these cases, and it may spread to the motor cortex from the lateral sinus by the inferior anastomotic vein, or from the superior longitudinal sinus by the superficial middle cerebral vein, the variation in the pathways and differing rate of spread accounting for the diversity of modes of onset.

Other areas of the brain may also be affected, as evidenced by impairment of sight or speech, and a careful search should always be made for such associated lesions.

The fact that arterial changes have been found in a few necropsies does not alter this conclusion, as rare cases with widespread arterial disease are the very cases in which the result is likely to be fatal, and it has been shown that recovery is common even after extensive intracranial venous thrombosis.

Treatment with anticoagulants and antibiotics is strongly indicated in view of the severe effects of the thrombosis.

\section{Summary}

Acute infantile hemiplegia is briefly described, and the findings in 10 cases noted. Two of these cases showed features pointing to intracranial venous thrombosis as a cause.

The cause and effect of intracranial venous thrombosis are discussed, and illustrative cases described.

It is concluded that venous thrombosis due to a minor upper respiratory infection may be the cause of many cases of this syndrome, and that division of cases into those with and those without obvious infection is unnecessary.

Treatment with anticoagulants and antibiotics is advised in those cases which are due to venous thrombosis.

I wish to thank Professor R. W. B. Ellis, Dr. D. N. Nicholson and Dr. J. L. Henderson for permission to use their case records, and Dr. A. R. MacGregor for the necropsy report. I am most grateful to Dr. G. I. Scott for his help, and to Professor Norman Dott for his advice and criticism.

\section{REFERENCES}

Abercrombie, J. (1887). Brit. med. J.. 1, 1323.

Altschul, R. (1949). J. Neuropath. exp. Neurol., 8, 204.

Bailey, O. T. and Hass. G. M. (1937a). Brain. 60, 293. (1937b). J. Pediat.. 11, 755.

Bauer, G. (1946). Lancet, 1, 447.

Beck, D. J. K. and Russell. D. S. (1946). J. Veurosurg., 3, 337.

Byers, R. K. and Hass, G. M. (1933). Amer. J. Dis. Child.. 45, 1161.

Campbell, A. C. P. (1938). In - The Circulation of the Brain and Spinal Cord." Res. Publ. Ass. nerv. ment. Dis., 18, 561-2.

Courville, C. B. and Nielsen, J. M. (1935). Amer. J. Dis. Child.. 49, 1.

Dandy, W. E. (1946). Bull. Johns Hopk. Hosp., 79, 34.

Dott, $\dot{N}$. M. (1951). Personal communication.

Dowman, C. E. (1926). Arch. Neurol. Psychiat., Chicago, 15, 110. 
Ebbs, J. H. (1937). Archives of Disease in Childhood, 12133.

Ellis, R. W. B. (1937). Proc. roy. Soc. Med., 30, 768.

Foley, W. T. and Wright, I. S. (1950). Med. Clin. N. Amer., 34, 909.

Ford, F. R. and Schaffer, A. J. (1927). Arch. Neurol. Psychiat., Chicago, 18, 323.

Ghetti, G. (1909). Gazz. Osp. Clin., 30, 913. Abstracted in Brit. med. J., 1910, 1 Epit. 1.

Goldman, I. B. (1936). Laryngoscope, 46, 604.

Goodhill, V. (1944). J. Amer. med. Ass., 125, 28.

Gowers, W. R. (1888). "A Manual of Diseases of the Nervous System." London.

Hines, E. A. and Barker, N. W. (1949). Med. Clin. N. Amer., 33, 335.

Holmes, G. (1927). Lancet, 1, 957.

Jorpes, J. E. (1946). "Heparin in the Treatment of Thrombosis," 2nd ed. London.

Martin, J. Purdon (1944). Proc. roy. Soc. Med., 37, 383.

Maybaum, J. L. (1936). Laryngoscope, 46, 610.
Merwarth, H. R. (1942). Amer. J. Surg., 56, 526.

Norman, R. M. (1947). J. Neurol., Neurosurg. Psychiat., 10, 12.

Putnam, T. J. (1937): J. Amer. med. Ass., 108, 1477.

- and Alexander, L. (1938). In 'The Circulation of the Brain and Spinal Cord,' Res. Publ. Ass. nerv. ment. Dis., $18,544$.

Rabinovitch, J. and Pines, B. (1943). Surgery, 14, 669.

Salinger, S. (1923). Laryngoscope, 33, 27.

Shlevin, E. L. and Lederer, M. (1944). Ann. intern. Med., 21, 338.

Stewart, R. M. (1948). Edinb. med. J., 55, 488.

Strümpell, A. (1884). Jb. Kinderheilk., 22, 173.

Symonds, C. P. (1937). Brain, 60, 531.

- (1940). Brit. med. J., 2, 348.

de Takats, G. (1950). J. Amer. med. Ass., 142, 527.

Toomey, J. A. and Hutt, H. B. (1949). Amer. J. Dis. Child., 77, 285.

Wyllie, W. G. (1948). Proc. roy. Soc. Med., 41, 459. 